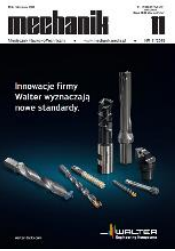

How to cite this article:

Authors: Janusz Kalisz, Daniel Toboła

Title of article: "The influence of surface topography on selected tribological properties of hardened $100 \mathrm{Cr} 6 \mathrm{steel}$ after turning"

Mechanik, No. 11 (2019)

DOI: https://doi.org/10.17814/mechanik.2019.11.95

\title{
The influence of surface topography on selected tribological properties of hardened 100Cr6 steel after turning
}

\author{
JANUSZ KALISZ \\ DANIEL TOBOŁA *
}

\begin{abstract}
Dr inż. Janusz Kalisz, janusz.kalisz@ios.krakow.pl, https://orcid.org/0000-0001-8348-6437 - Sieć Badawcza Łukasiewicz - Instytut Zaawansowanych Technologii Wytwarzania, Kraków, Polska

Dr inż. Daniel Toboła, daniel.tobola@ios.krakow.pl, https://orcid.org/0000-0001-7966-240X - Sieć Badawcza Łukasiewicz - Instytut Zaawansowanych Technologii Wytwarzania; Kraków, Polska
\end{abstract}

Results of surface topography analysis and selected tribological properties of samples of $100 \mathrm{Cr} 6$ bearing steel after turning with variable feed are presented. The hardness of samples after heat treatment carried out in a vacuum furnace (including quenching and double tempering) was $60 \pm 1 \mathrm{HRC}$. The influence of turning feed on surface topography after machining as well as selected tribological properties were found. Depending on the surface topography of samples, differences between values of friction coefficients and wear rates were about $25 \%$. Moreover, along with the surface roughness changing, different nature of wear was found.

KEYWORDS: surface roughness, bearing steel, turning, coefficient of friction, wear

\section{Introduction}

Volume of surface layer represents only a few percent of entire element, however its stereometric and physicochemical properties decide on the intensity of the wear process [1]. Roughness is one of the modes to describe the surface finish quality of workpiece [2]. To characterise and classify different surfaces, the roughness parameters have been developed and normalised. The most frequently roughness parameter used to surface quality assessment is $R a$ - arithmetical mean deviation of the roughness profile. For the purposes of contact surface assessment is used material distribution curve (Abbott-Firestone curve), which represents profile material distribution as a function of the cutting height. The surface can have similar or even identical value of $R a$ (shown in Fig. 1), however it may considerably differ e.g. in material ratio of roughness profile [3].

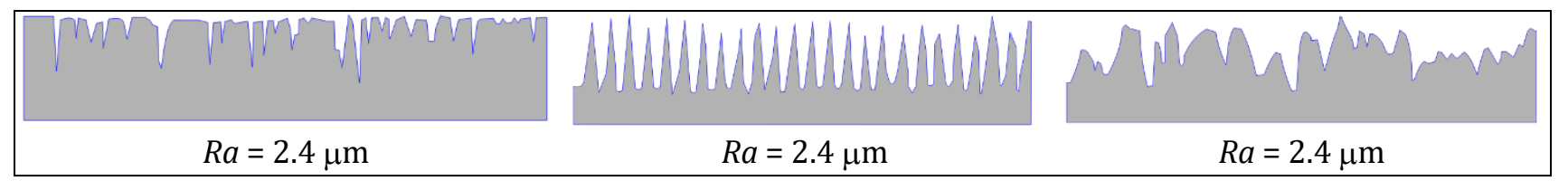

Fig. 1. Examples of the surface roughness profiles with the same value of the Ra parameter, but with different distribution of profile ordinates (based [4])

Definition of functional properties of surface geometric structure (SGS) presented in monograph [5] indicates that they are closely related to the geometric shape of the surface and geometric parameters depending on the applicable shaping techniques and create the specific chain: functional properties - geometric parameters - shaping technique - geometric shape.

Currently, ecological and economic factors play an important role in the technology development. When taking them into account it is possible to increase the efficiency of mechanical systems and reduce friction loss by applying the new surface treatment and tools from new, advanced materials.

The necessity to increase mechanical systems efficiency and reduce friction loss occur e.g. in bearings of drive systems of devices used in transport. Improvement of efficiency and durability increase of machine parts 
in the automotive industry results in lower fuel consumption and the reduction of greenhouse gas emissions. This can be obtained by usage the knowledge about the tribological properties of contact surfaces. Unfortunately, test results on the impact of surface topography on tribological properties of contact surfaces are not always used in practice. With the development of different ways of mechanical elements manufacturing, it is possible to obtain the surface with diversified geometric structure, which reflect different tribological properties. Surface roughness has a considerable impact, among other, on: friction in dry and lubricating conditions, lubricant film formation or load-carrying capability [6-10]. Taking into account the little impact of cutting speed on surface roughness [11], the aim of the carried out studies was determination of the effect of surface topography obtained after turning with variable feed (in range $0,05 \div 0,35 \mathrm{~mm} / \mathrm{rev}$ ) on tribological properties of $100 \mathrm{Cr} 6$ bearing steel samples. A correlation between selected surface geometric structure (SGS) parameters and wear resistance of shaped surface layer was analysed.

\section{Experimental procedure}

$100 \mathrm{Cr} 6$ bearing steel commonly used in the industry was examined. The chemical composition of this steel is shown in Table I. Initial machining included cutting the bars for samples of dimensions shown in Fig. 2. Then heat treatment was carried out, which consisted of hardening and double tempering. Samples hardness of about $60 \pm 1$ HRC was obtained.

During the next stage, face surface turning of samples with polycrystalline cubic boron nitride (PCBN) inserts was carried out. Turning parameters are given in Table II.

TABLE I. Chemical composition of 100Cr6 steel (AISI 52100)

\begin{tabular}{|c|c|c|c|c|c|c|c|}
\hline $\mathrm{C}$ & $\mathrm{Mn}$ & $\mathrm{Si}$ & $\mathrm{P}$ & $\mathrm{S}$ & $\mathrm{Cr}$ & $\mathrm{Ni}$ & $\mathrm{Cu}$ \\
\hline 1.01 & 0.34 & 0.21 & 0.010 & 0.009 & 1.41 & 0.10 & 0.12 \\
\hline \multicolumn{10}{|c|}{} \\
\hline
\end{tabular}

Fig. 2. Dimensions of tested samples

For abrasion resistance tests the ball-on-disc method and universal tester UMT-2MT from CETR were used. This method is suitable for tribological properties tests, i.e. friction coefficient and wear factor of materials working together at room temperature or elevated temperature. As a counter-specimen the $\mathrm{Al}_{2} \mathrm{O}_{3}$ ceramic polished, ball of $6 \mathrm{~mm}$ diameter was used. In each test, the sample worked together with the new ball surface. In each case the ball was washed in acetone and after drying placed in a holder. Sample surfaces were washed in alcohol and left for complete drying. In the performed tests the following parameters were applied: load $F_{\mathrm{n}}=2$ $\mathrm{N}$, friction path $L=1200 \mathrm{~m}$, friction linear speed $v=6000 \mathrm{~mm} / \mathrm{min}$, number of cycles $N=47746$, friction path radius $r=4 \mathrm{~mm}$, test time $t=200 \mathrm{~min}$. Tests were carried out at ambient temperature $22 \pm 2^{\circ} \mathrm{C}$ and with relative humidity of $60 \%$.

TABLE II. Turning parameters of face surfaces of $100 \mathrm{Cr} 6$ steel samples

\begin{tabular}{|c|c|cc|}
\hline Insert type & Cutting speed $v_{\mathrm{c}}[\mathrm{m} / \mathrm{min}]$ & Feed $f[\mathrm{~mm} / \mathrm{rev}]$ & Cutting depth $a_{\mathrm{p}}[\mathrm{mm}]$ \\
\hline NP-SNGA120412GS2 MB730 & 75 & $0.05 \div 0.35$ & 0.2 \\
\hline
\end{tabular}

Measurements of surface topography together with wear marks analysis were performed using TOPO 01P contact device (design of The Łukasiewicz Research Network - The Institute of Advanced Manufacturing Technology). The profilometer is equipped with measuring head of $1 \mathrm{~mm}$ range, with diamond tip with $2 \mu \mathrm{m}$ radius and $60^{\circ}$ cone radius. The areas of $4 \times 3.4 \mathrm{~mm}$ were measured, with scanning densities: $0.5 \mu \mathrm{m}$ in measurement axis and $10 \mu \mathrm{m}$ in perpendicular direction to the measurement. The geometrical state of the surface layer was determined by the measurement of surface roughness in 3D system according to ISO 25178 and EUR 1517 EN standards. During processing of measured data Gaussian filtration according to ISO 16610-21 was used. Quality changes of the examined surfaces related to stereometric charts and material ratio charts with indicated roughness core were analysed. Statistical analysis of selected height roughness parameters and core roughness parameters was performed. 
Based on measured wear track section area, the volume of removed material was calculated as a product of section area and wear track perimeter's length. Diagram describing measurement method and volume measurement of worn material are shown in publication [12].

\section{Tests results}

Measurement results of selected roughness parameters in 3D systems on samples face surfaces are shown in Table III. Taking into consideration the variable turning feed, obtained results were divided into three groups:

- I: $f \leq 0.10 \mathrm{~mm} / \mathrm{rev}$,

- II: $f>0.10 \leq 0.20 \mathrm{~mm} / \mathrm{rev}$,

- III: $f>0.20 \leq 0.35 \mathrm{~mm} / \mathrm{rev}$.

Analysis of results revealed that the smallest values of roughness height parameters were obtained for samples turned with feed $f<0.10 \mathrm{~mm} / \mathrm{rev}$, while the value of these parameters increased proportionally with increasing feed.

TABLE III. Average values of selected roughness parameters after turning of $100 \mathrm{Cr} 6$ steel with constant speed and depth of cut

\begin{tabular}{|c|c|c|c|c|c|c|c|c|c|}
\hline Group & Feed $f[\mathrm{~mm} / \mathrm{rev}]$ & $S a[\mu \mathrm{m}]$ & $S p[\mu \mathrm{m}]$ & $S v[\mu \mathrm{m}]$ & $S z[\mu \mathrm{m}]$ & $S k u$ & $S k[\mu \mathrm{m}]$ & $S p k[\mu \mathrm{m}]$ & $S v k[\mu \mathrm{m}]$ \\
\hline \multirow{3}{*}{ I } & 0.05 & 0.07 & 0.29 & 0.33 & 0.62 & 3.2 & 0.19 & 0.06 & 0.10 \\
\cline { 2 - 10 } & 0.08 & 0.17 & 0.50 & 0.55 & 1.05 & 1.9 & 0.55 & 0.07 & 0.14 \\
\cline { 2 - 10 } & 0.10 & 0.22 & 0.78 & 0.74 & 1.53 & 2.2 & 0.70 & 0.19 & 0.14 \\
\hline \multirow{3}{*}{ II } & 0.15 & 0.52 & 1.70 & 1.02 & 2.71 & 2.2 & 1.09 & 1.07 & 0.10 \\
\cline { 2 - 10 } & 0.18 & 0.78 & 2.18 & 1.31 & 3.49 & 2.0 & 1.45 & 1.68 & 0.08 \\
\cline { 2 - 10 } & 0.20 & 0.96 & 2.74 & 1.56 & 4.30 & 2.1 & 1.68 & 2.01 & 0.07 \\
\hline \multirow{3}{*}{ III } & 0.25 & 1.52 & 4.11 & 2.29 & 6.40 & 2.1 & 2.41 & 3.34 & 0.07 \\
\cline { 2 - 10 } & 0.30 & 2.19 & 6.08 & 4.40 & 10.47 & 2.1 & 3.78 & 4.60 & 0.84 \\
\cline { 2 - 10 } & 0.35 & 3.01 & 8.01 & 5.67 & 13.68 & 2.0 & 5.29 & 6.27 & 0.63 \\
\hline
\end{tabular}

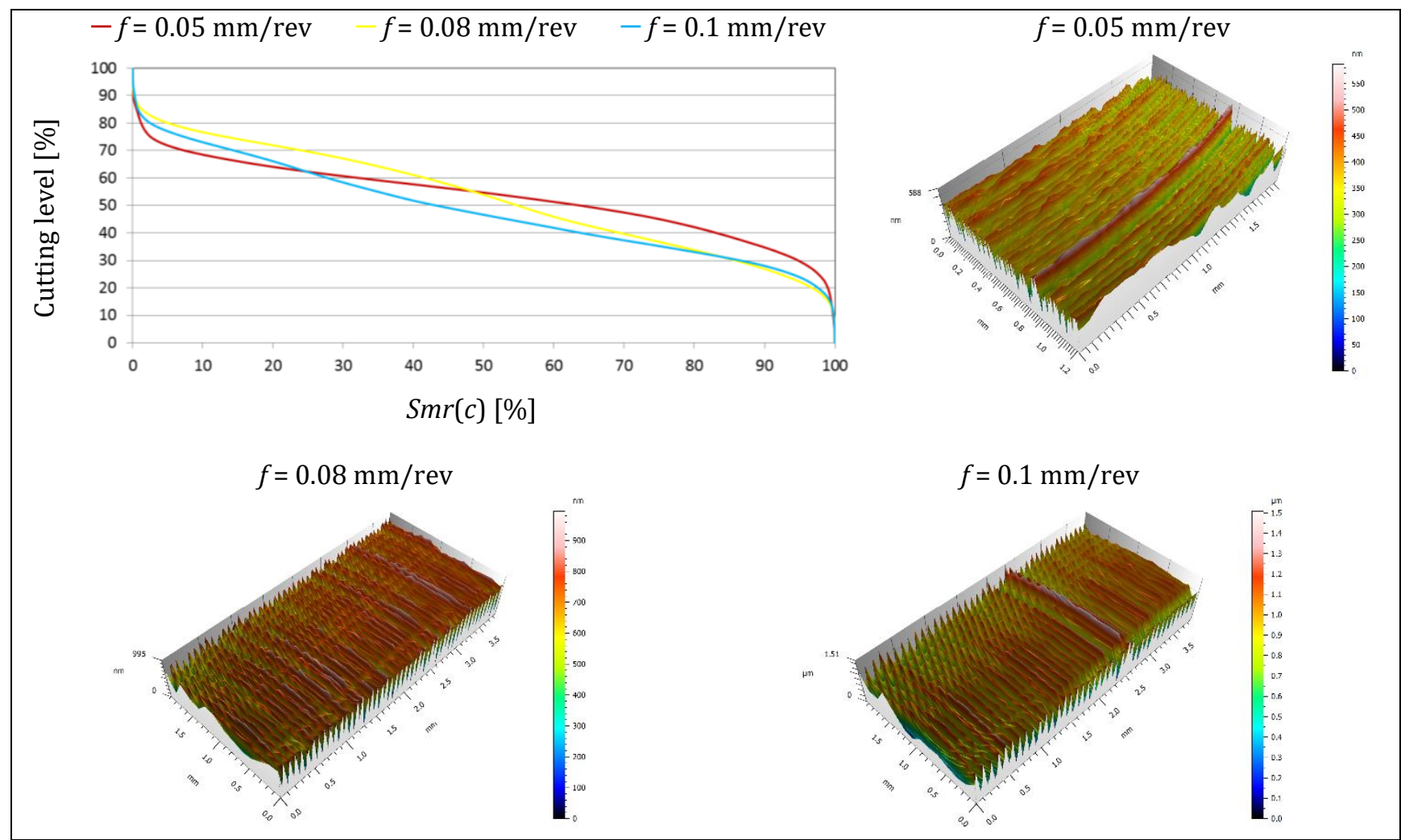

Fig. 3. Comparison of material ratio of the profile and surface topography after turning with feed: $f=0.05 \mathrm{~mm} / \mathrm{rev}, f=0.08 \mathrm{~mm} / \mathrm{rev}$ and $f=0.1 \mathrm{~mm} / \mathrm{rev}$ 


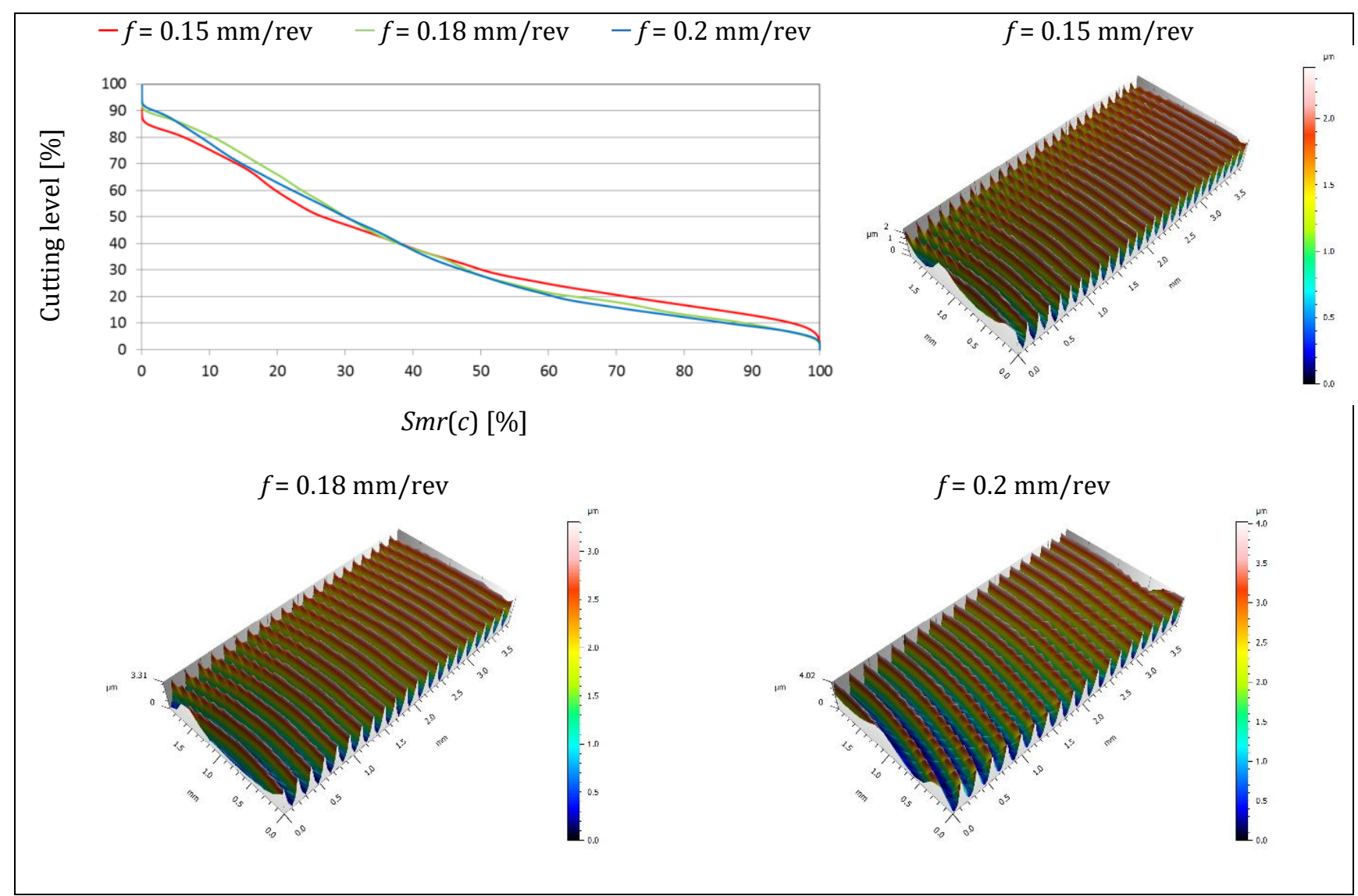

Fig. 4. Comparison of material ratio of the profile and surface topography after turning with feed: $f=0.15 \mathrm{~mm} / \mathrm{rev}, f=0.18 \mathrm{~mm} / \mathrm{rev}$ and $f=0.2 \mathrm{~mm} / \mathrm{rev}$

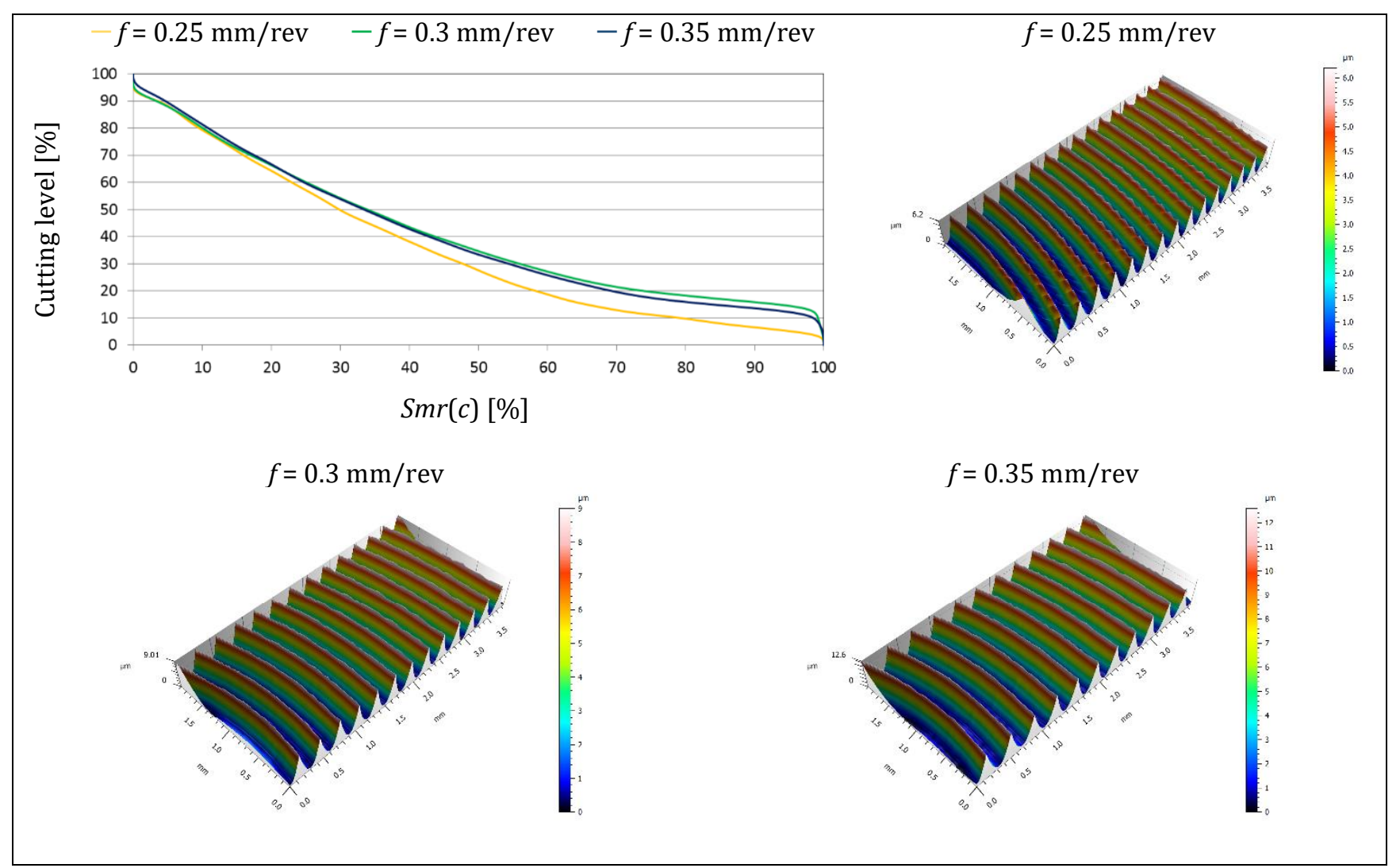

Fig. 5. Comparison of material ratio of the profile and surface topography after turning with feed: $f=0.25 \mathrm{~mm} / \mathrm{rev}, f=0.3 \mathrm{~mm} / \mathrm{rev}$ and $f=0.35 \mathrm{~mm} / \mathrm{rev}$ 

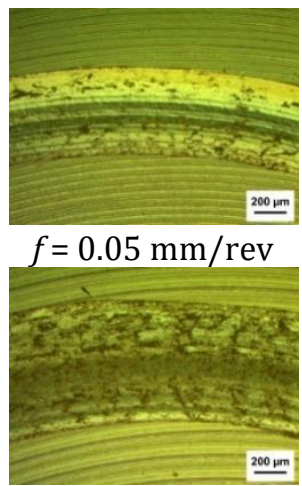

$f=0.15 \mathrm{~mm} / \mathrm{rev}$

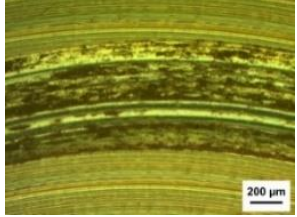

$f=0.25 \mathrm{~mm} / \mathrm{rev}$
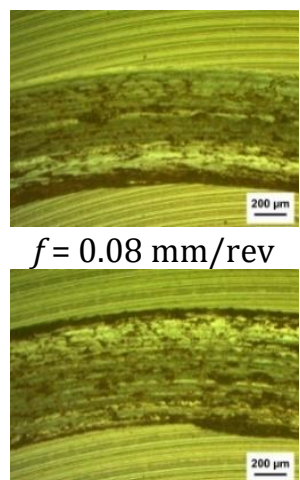

$f=0.18 \mathrm{~mm} / \mathrm{rev}$

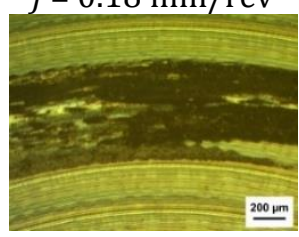

$f=0.30 \mathrm{~mm} / \mathrm{rev}$

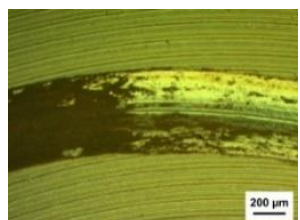

$f=0.10 \mathrm{~mm} / \mathrm{rev}$

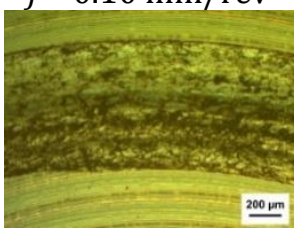

$f=0.20 \mathrm{~mm} / \mathrm{rev}$

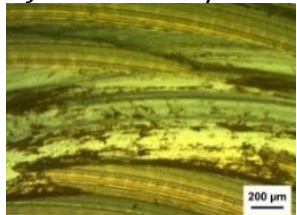

$f=0.35 \mathrm{~mm} / \mathrm{rev}$

Fig. 6. Microstructure of wear tracks after the ball-on-disc tests for the surface of samples made of $100 \mathrm{Cr} 6$ steel after turning with constant parameters $v_{\mathrm{c}}=75 \mathrm{~m} / \mathrm{min}$ and $a_{\mathrm{p}}=0.2 \mathrm{~mm}$ and variable feed

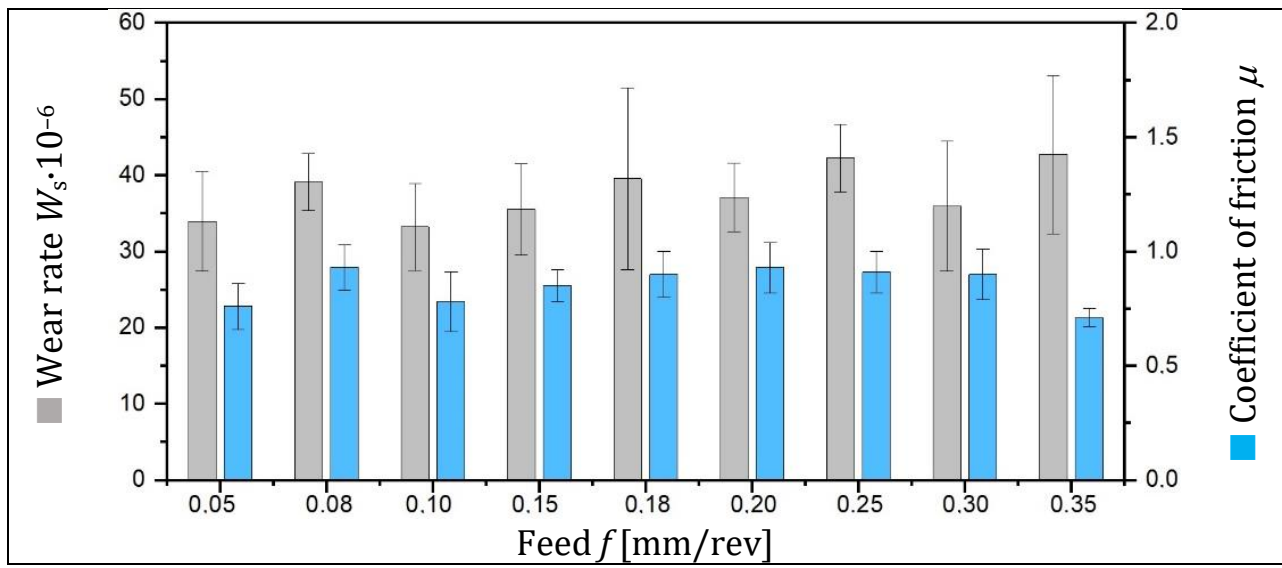

Fig. 7. Wear rates and coefficients of friction after the ball-on-disc test for 100Cr6 steel samples turned with constant parameters $v_{\mathrm{c}}=75 \mathrm{~m} / \mathrm{min}$ and $a_{\mathrm{p}}=0.2 \mathrm{~mm}$ and variable feed

Surface load bearing properties were evaluated with spatial parameters distribution of roughness core: reduced peaks height $S p k$, reduced core height $S k$ and reduced dales height $S v k$. As a result of the analysis has been stated that with the decrease of the parameter $S p k$ value a smaller material allowance for lapping during operation can be predicted. This also indicates better tribological properties. The smallest parameter $S p k$ values were obtained for feed $f<0.1 \mathrm{~mm} / \mathrm{rev}$.

According to the literature data [13] greater dales height Svk than peaks Spk contribute to the retention improvement and increase the ability to liquid collection in voids of dales in the zone below the core.

Measured low parameters $S k$, $S p k$ and $S v k$ values after turning with feed $f<0.1 \mathrm{~mm} / \mathrm{rev}$ demonstrate, that favourable material distribution of roughness profile and good surface load bearing properties were obtained. Surface slope coefficient (kurtosis) Sku informs about distribution of irregularities on analysed surfaces. Parameter $S k u=3$ value suggests even distribution of irregularities, including defects on the surface. The most advantageous distribution of irregularities was obtained for feed $f=0.05 \mathrm{~mm} / \mathrm{rev}$.

Microstructures of worn marks after ball-on-disk test are shown in Fig. 6. They show different character of wear of individual surfaces obtained after turning with different feed. The reason for this development is changing contact between sample surface and counter-specimen. However, the mechanism that can explain results of wear, is shearing or chipping of peaks of surface irregularities under a force applied on the sample [14].

In addition, it should be noted that crucial importance for the course of tribological pair wear may have a phenomenon of material transfer from a surface with lower hardness to a surface of material with higher hardness. It results in sliding friction between those materials, which may be accompanied by strong adhesion manifesting itself as mat wear tracks on the sample surface. 
Wear rates and friction coefficients values determined after tribological test are shown in Fig. 7. Analysis of results revealed that the differences between the wear resistances of individual surfaces shaped by turning with different feed have been around aprox. $25 \%$, and average values of friction coefficients were in range $0.71 \div 0.93$. Studies confirmed that changing contact of two bodies (counter-specimen with a sample surface with different SGS) affects the change of the tribological properties of $100 \mathrm{Cr} 6$ steel surface layer. Turning feed change results in the extension or reduction of the machining time. In some less demanding applications, where surface roughness is not a key factor, is possible even doubling of feed (e.g. from 0.15 to $0,30 \mathrm{~mm} / \mathrm{rev}$ ), which saves time keeping similar surface tribological properties.

The Institute's research indicates that beyond the usually used mechanical processes of surface treatment (e.g. turning in hardened state), sequencial treatments (e.g. combining mechanical and thermo-chemical processes) bring enormous benefits from a perspective of the tribological properties. Synergy effect for selected tool steels after applying sequential processes in order to modify their surface layer was shown in previous publications $[12,15,16]$.

\section{Summary}

Based on the results of the research, was found the impact of turning feed on selected tribological properties of the $100 \mathrm{Cr} 6$ steel samples. The differences between the wear coefficients values of evaluated surfaces were around $25 \%$ - has been observed the changing wear character. It has been demonstrated that depending on machined surface roughness there is a change in the friction coefficient, which average values, under conditions of the test, were in the range $0.71 \div 0.93$.

The research was financed as part of the statutory activity of The Eukasiewicz Research Network - Institute of Advanced Manufacturing Technology (DS.16-1.1).

\section{REFERENCES}

[1] Matuszewski M. „Kierunkowość struktury geometrycznej powierzchni w transformacji warstwy wierzchniej”. Rozprawa doktorska. Bydgoszcz, 2013.

[2] Sahin M., Cetinarslan C.S., Akata H.E. "Effect of surface roughness on friction coefficients during upsetting processes for different materials". Materials and Design. 28 (2007): 633-640.

[3] Adamczak S. „Pomiary geometryczne powierzchni. Zarysy kształtu, falistość i chropowatość”. Warszawa: Wydawnictwo Naukowo Techniczne, 2008.

[4] Krzos J. „Struktura geometryczna powierzchni”. Obróbka Metalu. 1 (2012): 56-65.

[5] Oczoś K.E., Liubimov V. „Struktura geometryczna powierzchni. Podstawy klasyfikacji z atlasem charakterystycznych powierzchni kształtowanych". Rzeszów: Wydawnictwo Politechniki Rzeszowskiej, 2003.

[6] Kalisz J. „Właściwości tribologiczne warstwy wierzchniej po obróbkach wykończeniowych stopu aluminium”. Mechanik. 7 (2018): 492-495, https://doi.org/10.17814/mechanik.2018.7.63.

[7] Mathia T.G., Pawlus P., Wieczorowski M. "Recent trends in surface metrology”. Wear. 271 (2011): 494-508.

[8] Sedlaček M., Podgornik B., Vižintin J. „Correlation between standard roughness parameters skewness and kurtosis and tribological behaviour of contact surfaces". Tribology International. 48 (2012): 102-112.

[9] Sedlaček M., Podgornik B., Vižintin J. "Influence of surface preparation on roughness parameters, friction and wear". Wear. 266 (2009): 482-487.

[10] Svahn F., Rudolphi Å.K., Wallén E. “The influence of surface roughness on friction and wear of machine element coatings". Wear. 254 (2003): 1092-1098.

[11] Zagórski I., Kulisz M., Warda T. „Wpływ parametrów technologicznych na chropowatość powierzchni po toczeniu oraz predykcja chropowatości z użyciem sztucznych sieci neuronowych". Mechanik. 10 (2018): 898-900, https://doi.org/10.17814/mechanik.2018.10.157.

[12] Toboła D., Brostow W., Czechowski K., Rusek P. "Improvement of wear resistance of some cold working tool steels”. Wear. 382-383 (2017): 29-39.

[13] Grzesik W., Żak K. "Comparison of surface textures produced by finish cutting, abrasive and burnishing operations in terms of their functional properties". Journal of Machine Engineering. 13, 2 (2013): 46-58.

[14] Dobrzański L.A. „Kształtowanie struktury i własności powierzchni materiałów inżynierskich i biomedycznych”. Gliwice: International OCSCO WORD PRESS, 2009.

[15] Toboła D., Brostow W., Czechowski K., Rusek P., Wronska I. "Structure and properties of burnished and nitride AISI D2 tool steel”. Materials Science - Medžiagotyra. 21 (2015): 511-516.

[16] Toboła D. "Impact of Mechanical Processes as a Pre-Sulphonitriding Treatment on Tribology Properties of Selected P/M Tool Steels". Materials. 12 (2019): 3431. 